\title{
Rumors of Golden Circle Activity In lowa During The Civil War Years
}

\author{
by Frank L. KLement \\ Phofessor of History, Marquette University
}

Mr. Klement, a member of the Advisory Council of the National Civil War Centennial Commission, earned his Ph.M. and Ph.D degrees in History at the University of Wisconsin under the direction of Professor William B. Hesseltine, noted Civil War scholar. A contributor to nearly two dozen historical journals and the author of two books, Copperheads in the Middle West and Wisconsin and the Civil War, Professor Klement has submitted the following article in which he challenges the long accepted legend of K.G.C. activity in Iowa during civil war years.

The emotionalism and excitement which accompanied the coming of the Civil War was fertile ground for rumors. Since stories about the Knights of the Golden Circle were popular throughout the upper Mississippi valley, it was natural that some Iowans spread and believed those tales. Governor Samuel J. Kirkwood and U. S. Marshall H. M. Hoxie used their offices to give respectability to the rumors. Consequently, another Iowa legend was written into history.

The Golden Circle tales which invaded Iowa had historical roots. They dated back to pre-Civil War days and to a dreamer named George Washington Lamb Bickley. Bickley lived near Cincinnati when he tried to organize the Knights of the Golden Circle as an anti-Catholic and expansionist society; he later planned a filibustering expedition intended to impose the "superior Anglo-American civilization" upon the "inferior" and Catholic Mexicans! ${ }^{1}$ His secret order was confined to paper,

1 George W. L. Bickley, "Statement of Facts," in the George W. L. Bickley Papers (War Department Records, The National Archives). Bickley at first tried to organize a branch of the Continental Uniona kind of successor to the Know-Nothing movement-in Cincinnati. Then, with a stroke of his pen, he gave birth to the Knights of the Golden Circle. 
although he publicly professed otherwise. Since he was a charlatan, drifter, pretender, and scamp rolled into one, there was no possibility that Bickley might realize his dream and pile up a fortune on ten-dollar membership fees. He did, however, pretend publicly that his society was real, extensive, and effective. He claimed to be a seer extraordinary and he appropriated the title of "General" to go with his pretentions."

Reports of K.G.C. activity made headlines throughout the first year of the war. Washingtonians heard rumors that the Golden Circle intended to seize the national capital. Kentuckians were told that Golden Circle members aided the proSouthern cause in the Blue Grass State. K.G.C. agents were blamed for explosions of steamboats and the burning of railroad trestles. Exposés of the Golden Circle, published in Cincinnati and Indianapolis, were broadcast over the Middle West as pamphlets. Republican politicians, in Ohio and Michigan, raised the K.G.C. specter to smear their Democratic opponents and influence the voters in the fall elections of 1861 . Some of those tales about the Golden Circle drifted into Iowa, stirring the imagination of the credulous and the gullible.

The Iowa setting was embroidered with tension in 1862. Sons of several prominent Iowa Democrats had joined the Confederate army, ${ }^{3}$ and the question of disloyalty was heatedly discussed. U. S. Marshall H. M. Hoxie made several arrests of Iowans accused of "secessionist tendencies." 4 Economic

2 The complex story of the Knights of the Golden Circle can be re-constructed from such sources as: Ollinger Crenshaw, "The Knights of the Golden Circle: The Career of George Bickley," American Historical Review, 47: 23-50 (Oct., 1941); the "exclusive story" printed in The Crisis (Columbus), Dec. 30, 1863; the expose published in the Cincinnati Daily Gazette, Aug. 6, 1863; several Bickley letters in the John Nicolay-John Hay Papers (Illinois State Historical Library); and the Bickley Papers (The National Archives).

3 Included in the number were two sons of George Wallace Jones, prominent Democratic politico, and a son of Stephen Hempstead, a former governor of Iowa.

4 Letter, James Harlan to Secretary of War [Edwin M. Stanton], Feb. 26, 1862, William H. Hill Papers (Civil War Political Prisoners Records, State Department Files, The National Archives); letter, Stanton to Harlan, March 10, '1862, ibid. George Wallace Jones, noted Iowan, was arrested on Christmas day, 1861. Jones' arrest received much newspaper publicity. 
conditions deteriorated and undermined the hold of the Republican party upon the electorate of the state. Democratic editors, like Dennis A. Mahony of the Dubuque Herald and Daniel Sheward of the Fairfield Constitution and Union, waged a vigorous and vicious war of words against the Lincoln Administration. ${ }^{5}$ In some sections of Iowa, especially in the larger cities, the Democracy enjoyed a resurgence.

Editor Jesse Clement of the Dubuque Times tried to stay the Democratic tide by creating a Golden Circle bogeyman. $\mathrm{He}$ expressed the belief that a branch of the Knights of the Golden Circle, or a similar serpentine society, operated in Dubuque. ${ }^{6}$ He implied that it was linked to the Democratic party and that treason hid behind closed doors. But Clement's contention failed to check the Democratic tide in the April, 1862, elections. The Democratic slate of city and county officers carried the elections. It was evident, to Editor Clement of the Times, that he would lose the post of county and city printer-the job would go to Dennis A. Mahony of the Dubuque Herald. As rivals in politics and business the two editors had only hate and scorn for each other. Editor Clement got a measure of revenge by smearing K.G.C. tar upon his political opponents. "Intimations have been given," he wrote snidely, "that the Knights of the Golden Circle were at work preparing to carry the Breckinridge [Democratic] ticket at all hazards, and that weeks ago colonization had been begun in the lower portions ['Dublin'] of the city." 7

Dennis A. Mahony of the Dubuque Herald refused to let the charge go unchallenged. He pointed out that Editor Jesse Clement, having made public charges, had the responsibility of offering evidence to substantiate those assertions. ${ }^{8}$ Under

5 "Grain has gone down till it won't pay hauling charges. So much for electing a man - the exponent of Personal Liberty Laws, Nigger Suffrage and Equality, Beecherism, Stoweism, Niggerism and a dozen isms and Tom fooleries upon which the entire North under the lead of Abolitionized Massachusetts has gone mad." - Dubuque Herald, Nov. 23,1861 .

6 Dubuque Daily Times, April 6, 1862.

7 Ibid., April 9, 1862.

8 Dubuque Herald, April 10, 1862. 
Mahony's prodding, Clement looked far afield for evidence. The best he could do was to produce a letter written by an unknown person in Kentucky, and Editor Clement printed that strange letter in his newspaper-it took three full columns of print. ${ }^{9}$ The long letter quoted extensively from a pamphlet (put forth by "the Union men of Kentucky") published and circulated by Kentuckians anxious to organize a Union League. That pamphlet or exposé dealt with the Knights of the Golden Circle, and it was supposedly the work of one who "had devoted considerable time and attention to this [K.G.C.] organization." Both the pamphlet and letter claimed that the Golden Circle was busy organizing a national network of "castles," with passwords, degrees, and a secret militia. The intent of the subversive society was "to infiltrate the ranks of the army and the departments of the government in Washington." That odious order, supposedly, preferred compromise to war, anarchy to order, and slavery to abolition. The K.G.C. was known by various names, such as Peace Party, Democratic Society or Democratic Association, and Constitutional Party. The closing paragraph of the letter combined an explanation with advice:

The work of the K.G.C., as used here, is revised and changed from that used six months ago in the Southern States. In the first degree, but little of its real character is divulged. It is represented simply as a society to oppose abolition. Little by little the candidate is led into the vortex of treason. I earnestly warn all good men against taking the first step.10

While Mahony scoffed and Democrats ridiculed the shabby evidence, other Republican editors came to the support of Editor Clement and the Dubuque Times. The Chicago Tribune called Dubuque a "sinkhole of secession" and asserted that a Golden Circle "castle" existed in the city. ${ }^{11}$ The Washington, D. C., correspondent of the New York Tribune wrote: "It is known here that a secret organization exists in Dubuque,

9 Dubuque Weekly Times, April 17, 1862.

10 Ibid.

11 Quoted in the Dubuque Daily Times, May 8, 1862. Later the Chicago Tribune referred to Dennis A. Mahony as "the Dubuque traitor; the spawn of a felon's cell." - quoted in Franklin T. Olds, ed., History of Dubuque County, Iowa (Chicago, 1911), 291. 
Iowa, to resist the collection of federal taxes." 12 That anxious correspondent added a ward of warning: "The ringleaders in this movement are known to the Government, and its eye is upon them."13 The editor of the Dubuque Times appreciated the aid he got from the New York Tribune and he added an editorial note:

The telegraphic dispatches of yesterday brought the mortifying intelligence that it was known at the capital that there was a secret league of secessionists in this city who were intending to resist the collection of the Federal tax ... Doubtless this is no idle surmise or idle rumor, but the result of actual knowledge. 14

Mahony of the Herald demanded an investigation of the "alleged rumors." He wanted those who circulated the stories and charges questioned. He believed the charges were "false and malicious." The Herald contained his disbelief of the charges and his distrust of those who cried "Wolf! Wolf!"15

Iowans had a respite from K.G.C. tales until August of 1862. There were two reasons why Republicans ressurrected the K.G.C. bogeyman in the fall of that year. In the first place, the fall elections were in the offing and the Democratic party was reorganized and hopeful. In the second place, U. S. Marshall $\mathbf{H}$. M. Hoxie made a dozen arbitrary arrests-including Mahony of the Dubuque Herald and Daniel Sheward of the Fairfield Constitution and Union. ${ }^{16}$ Marshal Hoxie, who doubled as a member of the Republican State Central Committee tried to silence outspoken Democrats through arbitrary action-the public reaction was tremendous. Hoxie needed to justify the arrests-reconstructed K.G.C. charges were the sop thrown to the populace.

The Iowa State Register led the defense of the arrests and

12 Quoted in the Dubuque Herald, May 8, 1862.

13 Ibid.

14 Dubuque Daily Times, May 8, 1862.

15 Dubuque Herald, May 8, 1862.

16 Hoxie's fall roundup netted both major and minor political figures. Mahony and Sheward were widely known. Such partisan Democrats as James Corban Taylor (Clark county), Joseph K. Evans and William Evans (Madison county), and John Strohl (a farmer residing near Centralia, Dubuque county) were less well known. Hoxie's inability to justify the arrests to the satisfaction of Secretary of War Stanton caused Hoxie some embarrassment. Stanton sent John Hay, as special agent to the War Department, to investigate the wholesale arrests in Iowa. 
raised the K.G.C. smoke screen. The Register charged that treason was widespread and that the Knights of the Golden Circle possessed a statewide organization in Iowa. That imaginative editor charged that 10,000 Iowans belonged to the subversive order and that the Iowa lodge was linked to its Missouri counterpart. ${ }^{17}$ Hoxie, the jittery and politicallyminded U.S. Marshal, contended that ten of those whom he arrested were active in the Golden Circle $^{18}$-a contention out of line with the evidence.19 Both Governor Kirkwood and Marshal Hoxie wrote to Edwin M. Stanton, Secretary of War, that the arrests made effectively checkmated that serpentine society. "Lodges exist," wrote Governor Kirkwood, "in almost every county in the State." He added that the order shipped ammunition to the South, cooperated with Confederate commander Sterling Price, and gave "aid and comfort to the Rebellion."20 Hoxie wrote that he feared an open rebellion and that K.G.C. members were armed and organized in Madison county. He was sure that the Golden Circle intended to resist the execution of the laws and that peace was endangered. ${ }^{21}$

17 Iowa State Register (Des Moines), Aug. 20, 27, Sept. 17, 1862; Dubuque Herald, Aug. 20, 21, 1862.

18 Report, H. M. Hoxie to John Hay, Nov. 1, 1862, Lafayette C. Baker-Levi C. Turner Papers, 1862-1865 (Adjutant General's Records, War Department Files, The National Archives); letter, John Hay to Secretary of War [Edwin M. Stanton], Nov. 19, 1862. ibid.

19 Hoxie's evidence consisted of a report by George Rose and affidavits of J. E. Painter and William Snooks. Rose was an Iowa resident (Madison county) arrested in Missouri for smuggling arms. He was turned over to Hoxie and jailed. Two weeks later, to get his release and a detective's appointment, Rose told Hoxie a story of Golden Circle activity and his work in that order. Rose, commissioned special investigator, subsequently attended a Democratic caucus in Winterset. His imagination transformed the Democratic party caucus into a K.G.C. castle. The Painter-Snooks affidavits claimed that a statewide subversive order, sympathetic to the Confederacy, was linked to the Democratic party. It is noteworthy that the Madison county man whom an affidavit named as secretary of a K.G.C. lodge was an illiterate.

Rose's report and the affidavits of Painter and Snooks are in the Baker-Turner Papers - not available to researchers until 1952. 20 Letter, Samuel J. Kirkwood to Hon. Edwin M. Stanton, Sept. 11,
1862, Baker-Turner Papers.

21 Letter, H. M. Hoxie to Hon. Edwin M. Stanton, Sept. 18, 1862, ibid. Hoxie added, "I have detailed an experienced detective to ascertain the truth of my information." The "experienced detective" was none other than George Rose, rascal extraordinary. 
Dennis A. Mahoney ${ }^{22}$ and Daniel Sheward, meanwhile, protested their innocence from their cells in Old Capitol Prison, Washington, D.C. Both Iowa editors signed an affidavit denying their membership in the Knights of the Golden Circle or any other treasonable organization. ${ }^{23}$ They were, however, kept in confinement until the fall elections were over. After their release, without any charges being formally filed, Mahony and Sheward returned to their respective homes in Iowa.

The first six months of 1863 witnessed the high tide of Midwestern Copperheadism-opposition to the Lincoln Administration was deep and widespread. ${ }^{24}$ There was intense criticism of Lincoln's Emancipation Proclamation. ${ }^{25}$ Defeat-

22 Mahony, colorful Copperhead and curmudgeon, has attracted the attention of a number of scholars, e.g., Roger J. Sullivan, Mahony the Unterrified (B.A. thesis, Loras College, 1938); Edward J. Goodman, Copperheadism in Dubuque during the Civil War (M.A. thesis, Loras College, 1938); Helen Wukow, Dubuque in the Civil War Period (M.A. thesis, Northwestern University, 1941); and Hubert W. Wubben, "Dennis A. Mahoney and the Dubuque Herald, 1860-1863," Iowa Journal of History, 56: 289-320 (Oct., 1958). Mahony's own account of his arrest and imprisonment is reported in Dennis A. Mahony, The Prisoner of State (New York, 1863).

23 Affidavit, Nov. 11, 1862, signed by Mahony et al, in Baker-Turner Papers. The K.G.C. charges against Sheward were based upon an affidavit of questionable worth - the affidavit's "character for honesty, integrity and loyalty can at any time be impeached." The affidavit was labeled a "Keokuk renegade" - letter, Bernhard Henn to Charles Mason, Sept. 1, 1862, Charles Mason Papers (State Department of History and Archives, Historical Library, Des Moines).

24 Iowa Copperheadism has been treated in two separate studies. See Frank C. Arena, "Southern Sympathizers in Iowa during the Civil War Period," Annals of Iowa, 30: 486-538 (Jan., 1951), and Robert Rutland, "The Copperheads of Iowa: A Re-Evaluation," Iowa Journal of History, 52: 1-30 (Jan., 1954). Arena treats Iowa's Copperheads as sympathizers with the South. Rutland, more realistically, sees Democratic partisanship as the chief ingredient of Iowa Copperheadism.

25 LeGrand Byington to "My Dear Wife," February 13, 1863, LeGrand Byington Papers (microfilm copy, State Historical Society of Iowa); Dubuque Herald, Jan. 3, 1863. Byington, a Democratic congressional candidate in 1862, wrote from Washington: "The lunatics who dominate here will stop at nothing short of a reign of terror and utter anarchy." Mahony recorded his opposition to emancipation policy in the editorial columns of the Dubuque Herald. Mahony wrote: "The people who submit to the insolent fanaticism which dictated his last act [the Emancipation Proclamation], are and deserve to be enslaved to the class which Abraham Lincoln self-sufficiently declares free. If they.possess a tithe of the spirit which animated Rome when Cataline was expelled from its walls . . . they would hurl him into the Patomic, Cabinet, Congress, and all." 
ism was a popular malady, for Union defeats were many and disheartening. ${ }^{26}$ The arrest of Clement L. Vallandigham and the summary treatment accorded him prompted Democrats everywhere to protest. ${ }^{27}$ Federal conscription, like a threatening cloud, darkened the horizon. Republican political fortunes were at a low ebb.

Republican party strategists countered by generating nationalism and organizing the Union League. Governor Kirkwood and the party bosses created the Union League as a secret arm of the Republican party. Organized at Ottumwa on March 20, 1863, the Union League spread rapidly. The State Council was established at Des Moines on June 16, 1863the eve of the Republican State Convention. To justify the creation of this secret if patriotic society, Republicans again raised the K.G.C. bugaboo. ${ }^{28}$ Dubuque Republicans claimed that a Union League was needed to counteract "an organized conspiracy in Dubuque to revolutionize the government." The Democratic editor of the Dubuque Herald analyzed the situation correctly: "These men have no knowledge of such an organization [the K.G.C.], for there is none. They are making this the pretext for their organization simply that they may be allowed to proceed without interference." 29

The success of the Union League in aiding Republicans to win the April, 1863, elections, ${ }^{30}$ encouraged Kirkwood \& Company to continue building the League and damning the Golden Circle. The editor of the Oskaloosa Herald invented an exposé, and it was copied and carried in most Republican newspapers. The Oskaloosa Herald claimed that Dubuque was the Iowa headquarters of the Knights of the Golden Circle and

26 Dubuque Herald, Feb. 13, 1863; letter, Charles Negus to Charles Mason, Feb. 14, 1863, Mason Papers.

27 Dubuque Herald, May 14, 1863.

28 Letter, Charles Negus to Charles Mason, Feb. 14, 1863, Mason Papers.

29 Dubuque Herald, March 11, 1863.

30 After its initial test at the polls in the April (1863) elections, a leading Dubuque Republican wrote: "Our Union organization is perfect, and we have good reason to be proud of the result of our first effort." - letter, George W. O'Brien to Dear Governor [Kirkwood], April 7, 1863, Samuel J. Kirkwood Papers (State Department of History and Archives, Historical Library, Des Moines). 
that Dennis A. Mahony and Stilson Hutchins (editor of the Dubuque Herald while Mahony was in New York preparing an anti-Lincoln book) were its high priests. The Oskaloosa Herald revealed that the information for its exposé of the K.G.C. came from a "dying soldier who did not wish to face death with two opposite oaths on his conscience." The "dying soldier" related that he had taken the K.G.C. oath while in the army-after taking the soldier's pledge. After joining the Golden Circle, he had organized "lodges" ainong his fellow soldiers. The "dying soldier" revealed the hailing sign, the K.G.C. grip, and the passwords of the order-including the sign to be used in battle, or when a soldier desired to desert to the enemy. ${ }^{31}$ The editor of the Oskaloosa Herald then noted that domestic traitors, á la mode the Golden Circle, wished to plunge the Northwest into anarchy and civil war. "Loyal people are stark mad," added the partisan editor, "if they do not, with redoubled diligence, perfect their organizations and thoroughly prepare themselves for defence, and for aiding the rightful authorities in executing the laws." 32

Not only was the K.G.C. strawman an excuse to organize the Union Leagues, but also an excuse for Governor Kirkwood to arm Union Leaguers and Republican-sponsored militia companies. Kirkwood asked Secretary of War Stanton for 5000 stands of arms to distribute to the "loyal men of the State." 33 The Iowa Governor justified that request by claiming that traitors were talking treason, "buzzing for Jefferson Davis," and "organizing the Knights of the Golden Circle." 34 U.S. Marshal H. M. Hoxie came to Governor Kirkwood's support with a couple of fancy tales of questionable worth. One was a report credited to an Osceola citizen who insisted that an association "of every Disloyal caracter" in Clark and Madison counties was disposed "to assume a verry hostill attitude." 35

31 Oskaloosa Herald (n.d.), quoted in the Dubuque Daily Times, May $7,1863$.

32 Ibid.

33 Official Records of the Union and Confederate Armies, Series 3, 2: 62 (128 vols., Washington, D.C., 1880-1901).

34 Ibid.

35 Letter, F. W. Johnson to ["H. Hoxy"] H. M. Hoxie, Feb. 18, 1863, Baker-Turner Papers. 
The effectiveness of the Union League tempted Democrats to create a partisan order of the same nature, but under the wing of the Democratic party. "I am also disposed to favor secret organization," one Democratic bigwig confided to his diary, "seeing how our antagonists have used it." 36

Democratic aversion to secret societies and the ease with which such organizations could be honeycombed with spies prompted Democrats to forgo such a partisan society. The Rev. Clement Smyth, Bishop of Dubuque, added the coup de gráce. Bishop Smyth asked Catholics of his diocese "to keep out of secret societies"-if they joined such organizations they might as well leave the Church. ${ }^{37}$ Bishop Smyth's remarks against political societies made the rounds of the press.

Union victories at Vicksburg and Gettysburg made the Lincoln Administration respectable again. War prosperity soothed some of the feelings of discontent and dismay which accompanied the depression of 1861-62 in Iowa and the Mid: west. ${ }^{38}$ Intra-party strife made the Democratic party a less effective political force. The Union League entrapped many who had once called themselves Democrats. Rumors of K.G.C. activity disappeared from the Republican newspapers. There was little need, during the remaining months of 1863 , to get the K.G.C. skeleton out of the closet and rattle its bones.

Republicans were in firm command in Iowa in early 1864 . H. M. Hoxie, federal marshal, and Josiah B. Grinnell, representing Iowa in the lower house of Congress, were the only ones who laid K.G.C. charges on the line. Hoxie, who saw disloyal Democrats behind every tree, wrote to Washington that Iowa Copperheads were organizing an association called the "Union Relief Society"-really only a new form for the old K.G.C. Hoxie asserted that every four townships constituted

36 Entry of Oct. 22, 1863, "Diary, 1863," Mason Papers.

37 Dubuque Daily Times, May 27, 28, 1863.

38 One newspaperman viewed war prosperity as "the lance of Achilles, healing by its touch the wounds of war and desolation." - Cincinnati Daily Gazette, Nov. 9, 1863. The war correspondent of the London Times, believed that a fat pocketbook hardened the conscience. "Nothing is strange," he wrote, "nothing is unusual, nothing is unconstitutional, nothing is wicked to people who are prospering upon the war . . ."The Times (London), March 17, 1863. 
a sundistrict which sent a delegate to a monthly county meeting. At these county meetings the new passwords, aims, projects, and orders were issued. For good measure, Hoxie reported the supposed oath of the subversive "Union Relief Society":

I solemnly swear that I will support the Constitution of the United States as it is; that I will resist draft of State or Federal authorities; that I will resist all the present orders of this administration; that I will do all in my power to unite the states of the Northwest with the Southern Confederacy. ${ }^{39}$

Congressman Josiah B. Grinnell's charge that Knights of the Golden Circle were active in southern Iowa was made upon the floor of the House of Representatives. Grinnell interrupted a speech of the Hon. Francis P. Blair, Jr., of Missouri. Blair debunked reports that there was a link between border ruffians and a subversive secret society. Grinnell, on the other hand, contradicted Blair, saying:

But, sir, I say there was a rebel correspondence between northern Missouri and the southern portion of my district for a. long time. I say these border men of Missouri, under the name of Missouri State militia, did conspire with men in southern Iowa to blow up the courthouse in one of the southwestern counties. They did come over there and unite themselves with the Knights of the Golden Circle for the purpose of resisting the draft and prevent Union men from filling up the quota of Iowa. 40

Blair countered by saying that Congressman Grinnell was building a mountain out of a molehill. Blair did admit that marauders did cross the border and commit depredations, but that horse-stealing and hen-roost robbing was not a Golden Circle activity-that "mere imaginary dangers" as to the K.G.C. existed. ${ }^{41}$

Although no Iowa-based exposé of subversive society activities was made in Iowa in 1864, readers of Republican newspapers were fed a steady diet of reports which originated in other Midwestern states. Brigadier-General Henry B. Carrington of Indiana concocted an exposé of the Sons of Liberty

39 Report, H. M. Hoxie to Maj. L. C. Turner, Feb. 24, 1864, Official Records, Series 3, 3: 68-69.

40 Quoted in Hon. F. P. Blair, The Jacobins of Missouri and Maryland: Speech of Hon. F. P. Blair of Missouri, Delivered in the House of Representatives, February 27, 1864 (n.d.p.), 9.

41 Ibid. 
(a lineal descendent of the Golden Circle) and that fantastic story had wide circulation throughout the North. Colonel John B. Sanderson, a provost marshal stationed in St. Louis, uncovered a mare's-nest in Missouri. His exposé concerned the Order of American Knights, and he proved a master at parlaying pittance into plenty. ${ }^{42}$ Both of the exposés were circulated in Iowa, and it was but natural for Iowans to wonder if either or both of the subversive orders had chapters or castles in the Hawkeye State. ${ }^{43}$

Governor William M. Stone, anxious to prove that he was as patriotic, imaginative, and adept at story-telling as his fellow-governors of the Midwest, claimed that the Sons of Liberty were active in Iowa. He wrote:

In several lodges of the 'Sons of Liberty,' a treasonable organization which now exists in every county, it was determined, after full consultation, to unite in organizing companies under the militia law, and use it to cover their movements from public observation. While pretending to drill as a militia company, they could use the peculiar tactics of their order, without being compelled, as now, to seek concealment in darkness, caves, and cellars. - Most of these lodges in the southern half of the State are in constant correspondence with their coadjutors in Missouri, and since the first day of July last they can bear me out in saying that their communications have been characterized by the most unblushing treason, both to the - Federal and State Governments. Couriers are now running regularly between lodges on either side of the State line, and much of the extraordinary tide of immigration now pouring in from Missouri, is invited here by Iowa conspirators under promise of fellowship and protection. And when you reflect that on the first day of August there were 33,000 members of this secret Order enrolled in this State, bound together by oaths which, if obeyed, renders every one of them an active traitor to the Union, and an abettor to civil strife in our State; that large quantities of arms and ammunition, purchased with means contributed by their moneyed men in this and other States, are being secretly brought into these counties to be used for disloyal practices, you may well con-

42 Carrington's activities as a teller of tall tales and Sanderson's effort to build the Order of American Knights as a reality rather than a fantasy are exposed in Frank L. Klement, The Copperheads in the Middle West, 134-205.

43 A special provost marshal of the War Department, called upon to supply names of prominent Midwesterners who belonged to subversive societies, listed the names of 41 persons "connected with the Sons of Liberty." Seventeen Missourians were listed, but not a single Iowan. Report, Lafayette C. Baker to Hon. Charles A. Dana, Sept. 3, 1864, Joseph Holy Papers (Library of Congress). 
ceive that the development of their nefarious military scheme, concocted in midnight conclaves, became with me a matter of serious concern.44

"I must either succomb to the machinations of these secret plotters against Government and law," added Governor Stone, "or adopt speedy and effectual measures to circumvent them." 45 If Governor Stone actually believed that three or 33,000 members of the Sons of Liberty could be found in Iowa, he was gullible indeed!

Bushwacker activities in the border counties were an excuse to restate the charges that either the Sons of Liberty or the Knights of the Golden Circle existed in Iowa. A squad of soldiers sent into Poweshiek county to arrest deserters clashed with a gang of bushwackers. Provost-marshal James Mathews reported: “ . . . the assassins were a sworn band of no trifling magnitude confederated together for disloyal purposes, one principal object being forcible resistance to the draft."46 When a guerrilla band of Missourians, dressed in Federal uniforms, raided into Davis county, Iowa officials evolved an interesting explanation: Governor Stone claimed that the bushwackers had been invited into Iowa by the Sons of $\mathrm{Li}$ berty of Davis county. ${ }^{47}$ Stone's partisan aides shouted "Amen!"

Although various Iowa officials and Republican newspaper editors contended that a subversive secret society operated in their state, not a shred of unimpeachable evidence substantiates those contentions. U.S. Marshal H. M. Hoxie and Governors Kirkwood and Stone gave the contentions a cloak of respectability, directing them into the stream of history. Marshal Hoxie raised the K.G.C. specter to undermine the re-

44 Letter, Gov. William M. Stone to Gen'l N. B. Baker, Sept. 12, 1864, in Report of the Adjutant General ... of the State of Iowa, January 11, 1863 to January 11, 1865 (Des Moines, 1865), 885.

45 Ibid.

46 Report, Captain James Mathews to Major Thomas Duncan, Oct. 1, 1864, published in Ibid., 1411-1412.

47 Report, Lt. Col. S. A. Moore to General N. B. Baker, Jan. 1, 1865, Ibid., 1419, 1428 . 
action to his many arbitrary arrests. Kirkwood used the K.G.C. bugaboo for political effect. That Knights of the Golden Circle existed in Iowa is simply a Civil War legend-a legend with nine lives.

\title{
My Friend Herbert Hoover
}

\author{
by Bill Wagner, Iowa Artist and Architect
}

Way back nearly ten years ago, I was approached by someone who knew of my interest in Iowa History about doing some drawings for the reconstruction of a blacksmith shop. Later I found out that two other architects had turned them down; but no matter now, their loss has been my gain. Somehow it was deemed worthwhile for me to go to New York and "interview" Mr. Hoover and find out what he could remember about the blacksmith shop. I went, I was received, and I was scared! Promptly, I was put a little more at ease when Mr. Hoover said, "I'm a little hard of hearing; you will have to talk a little louder." Frankly, I was so scared, I doubt if I was making any noise at all.

All he could remember was stepping on a live coal that fell out of the forge one day while watching his father ply his trade; he said that he still carried the scar. When it came time to go, I mustered courage and asked President Hoover if I could do a little "horse-trading." This appeared to be a new deal to him and he wanted me to explain. I said that I had made a pen and ink drawing of his birthplace and could I trade this to him for a photograph of himself. "That's easy," he said, "and would you like it signed?" This was more than I had hoped for. I returned home, framed his picture, and assumed my sketch was in the circular file.

The first of August, 1962, a special delivery air mail envelope came with instructions that the contents be put in 
Copyright of Annals of Iowa is the property of State of Iowa, by \& through the State Historical Society of Iowa and its content may not be copied or emailed to multiple sites or posted to a listserv without the copyright holder's express written permission. However, users may print, download, or email articles for individual use. 